\title{
LA LITERATURA MARGINADA, EL PAPEL DE LA CRÍTICA Y OTRAS CUESTIONES (1989)
}

En 1945, T.S. Eliot respondía a la pregunta de qué es un clásico utilizando términos como madurez, amplitud, universalidad, diciendo, en fin, que un clásico es "una obra que supera la prueba del tiempo". Mas como ha escrito el hispanista británico Keith Whinnom, el concepto de "clásico", que gracias a una mágica combinación de cualidades poco definidas se abre paso a través de la broza de una literatura anticuada para obtener un status de "sin tiempo" no solamente no nos ayuda, sino que puede llegar a ser positivamente pernicioso ${ }^{2}$.

Para el diccionario de la Real Academia Española, clásico es el autor o la obra "que se tiene por modelo digno de imitación en cualquier literatura o arte", lo cual parece añadir algo más de confusión al asunto. Mas en cualquier caso, son esas obras y esos autores considerados como clásicos los que suelen pasar a las historias de la literatura, en un fenómeno que no es, desde luego, privativo del mundo hispánico. Pero en las tres citas hechas poco más arriba se transparenta con toda obviedad -incluso en lo dicho por Whinnom- una interpretación idealista de lo que es literatura.

Veamos ahora el problema desde otro punto de vista, que puede parecer, en principio, escasamente apropiado. Consultemos otra vez el diccionario de la Real Academia. Así aparece en él la definición de heterodoxia: "Desconformidad con el dogma católico. Por extensión, desconformidad con la doctrina fundamental de cualquier secta o sistema". Y el ejemplo con el que se ilustra el vocablo es bien claro: "la heterodoxia de un escritor, de una opinión". Y veamos ahora qué es moral, según el mismo diccionario: "ciencia que trata del bien y de las acciones humanas en orden a su bondad o malicia". Todo son, sin duda, definiciones tan abstractas como idealistas y, desde luego, a-históricas. Pero lo fascinante es esa que indica que son los escritores quienes parecen particularmente proclives a la heterodoxia.

Si nos preguntamos el por qué un autor o una obra adquiere el honor de pasar a las historias de la literatura, habremos de cuestionarnos también qué es una historia de la literatura. Y si revisamos la mayoría de los más conocidos manuales del presente siglo, descubriremos que su contenido coincide con lo que suele llamarse cultura oficial. Una cultura oficial que, por otro lado, coincide a su vez con las normas impuestas por esos dos extraordinarios críticos que fueron Marcelino Menéndez Pelayo y Ramón Menéndez Pidal. Para el primero, en efecto, todo aquello que no fuera literatura y cultura católica no era digno de mención, sino para denigrarlo o ridiculizarlo; su Historia de los heterodoxos españoles es, en este sentido, modélica. Para el segundo, todo lo que no fuera realista y castellano o castellanizante no era auténticamente español ni valioso; baste recordar sus

1 T.S. Eliot, What is the Classic? (Londres, 1945). Traduzco al castellano todas las citas que hago de lenguas extranjeras.

2 Keith Whinnom. Spanish Literary Historiographv: Three Forms of Distortion (Exeter. 1967), 13-14. 
estudios sobre la épica y sobre todo sus Españoles en la literatura. Y para ambos, desde luego, lo español excluía, entre otras cosas, erotismo y sexualidad.

Quiere esto decir que los historiadores habituales de la literatura española, que han seguido animosamente durante generaciones la senda de los dos Menéndez, han ejercido -consciente o inconscientemente- una evidente censura sobre la literatura no oficial, esto es, sobre la literatura considerada como heterodoxa o de crítica religiosa, sobre la literatura de crítica social y política, y sobre la literatura erótica. Todo lo cual corresponde a unos presupuestos religioso-morales y político-sociales del historiador literario, los cuales, inquietantemente, coinciden también con los de otros censores de otros tiempos. Recordemos, como viejos ejemplos de celo puritano, las páginas arrancadas del Libro de Buen Amor o de varios cancioneros del siglo XV, la quema de la biblioteca del marqués de Villena en la Castilla de ese mismo siglo.

Después de todo lo dicho, podría añadirse ya que literatura marginada, en primera instancia, será aquella que se sale de las normas morales, religiosas, sociales o políticas oficiales, normas encarnadas habitualmente en sucesivas hornadas de críticos literarios. Pero la cosa es bastante más compleja. Pues, en efecto, ¿qué ocurre con un clásico que en su propia época no fue apreciado ni estimado? $\mathrm{O}$ al contrario, ¿qué ocurre con un autor que en su momento fue extremadamente conocido y leído y no ha pasado a las historias de la literatura, o todo lo más ha quedado relegado a una nota a pie de página o a lo que suele llamarse "la letra pequeña"? Para el primero de los casos mencionados, Keith Whinnom presenta el ejemplo del Poema de Mio Cid, sobre el cual dice:

No deseo denigrar la calidad literaria de esta obra, pero sospecho vehementemente que toda la evidencia objetiva nos lleva a la conclusión de que fue un fracaso artístico en su propia época ... Además, no puede demostrarse que el Cantar del Cid tuviese influencia alguna en el curso de la historia literaria española ... Pienso que no es posible escribir una historia de la literatura española correcta e inteligible si se concede a esta obra atípica el espacio y la importancia que habitualmente se le da como el primer gran monumento literario español ${ }^{3}$.

El propio Whinnom se pregunta cómo es posible que en las historias de la literatura ocupe más espacio la poesía de fray Luis de León -que sólo circulaba en forma manuscrita- que las novelas de caballerías, género absolutamente dominante junto con los poemas épicos cultos, unas y otros hoy perdidos en el olvido 4 . Podríamos añadir los casos de Teresa de Jesús y de la literatura -así llamada- mística y religiosa de la época de Felipe II. Que un autor, obra o género popularísimos en su momento no pasen, por otro lado, a la historiografía literaria, es algo notorio a lo largo de los siglos: la literatura cancioneril del siglo XV, la literatura del exilio español en los siglos conocidos como de Oro, el folletín del siglo XIX, la literatura erótica de los años veinte de nuestro siglo, la literatura proletaria de los años treinta, la del exilio republicano durante el franquismo... Pues, sin duda, un criterio que el crítico moderno ignora casi sistemáticamente, y que nunca debería olvidarse de aplicar, es la estima en que un autor era tenido por sus contemporáneos ${ }^{5}$.

3 Ibid., 16-17.

4 Ibid., 18.

5 Whinnom, ibid., 14. 
Y sigue diciendo Whinnom que: "El problema es que escribimos nuestras historias de la literatura con un desprecio casi total por la Historia, destacando las obras que nos atraen"6.

Ahora bien, lo que ocurre -y ya lo dije antes- es que esas obras "que nos atraen" y que los críticos destacan son, casualmente, las que coinciden con la literatura oficial (con notables excepciones; recuérdese Lazarillo de Tormes), esto es, con la cultura dominante. El crítico no debería olvidar que "los valores eternos" e inmutables de que se supone son portadoras las "obras maestras" han sido siempre difundidos por un aparato cultural que en nuestros días es (en las escuelas, por ejemplo) parte integral del aparato del Estado?.

Es decir, de la clase dominante, a la cual, por derecho propio o por afinidad ideológica, pertenecen la inmensa mayoría de los críticos, de los historiadores y de los profesores de literatura, así como sus productos, las historias de la literatura, las críticas. Un simple repaso a las páginas culturales de los grandes diarios de la España actual bastaría para probarlo, mas éste es otro tema.

Pero el problema del marginalismo literario es todavía más complicado ${ }^{8}$. Suele repetirse en sentido amplio y en buena medida abstracto, que la cultura es un elemento integrante de la nacionalidad, así como que se alimenta de las raíces de esa misma nacionalidad. Ahora bien, es preciso huir de toda metafísica y señalar con claridad que la cultura nacional de una comunidad dividida en clases no constituye un bloque compacto, que en ella se reflejan las contradicciones de esa comunidad. O de otro modo: que en las manifestaciones culturales de una determinada nacionalidad aparece, inevitablemente, su carácter de clase. Y por otro lado, lo que a primera vista pudiera parecer un todo nacionalcultural homogéneo (de acuerdo con las interesadas definiciones de la clase dominante) forma, en realidad, dos conjuntos claramente diferenciados y, a su vez, no sin fisuras propias: la cultura de esa clase dominante, la cultura de las clases dominadas. Lo que se llama cultura, en abstracto, suele coincidir con el concepto de cultura impuesto, precisamente, por la clase dominante. Así como la "unidad" de una sociedad dividida en clases se mantiene a través de los instrumentos del poder, la supuesta "unidad de la cultura" es mantenida muchas veces por esos mismos instrumentos, pues:

es obtenida mediante el predominio de la experiencia, la prédica y la normación culturales de la clase dominante; las experiencias y prácticas sociales que consagre la cultura "en general" serán las que esta clase seleccione, jerarquice e incorpore a la herencia cultural de toda la sociedad".

No estará de más señalar que así como el concepto habitual de cultura es el impuesto por los detentadores del poder político-social, también la historia de esa cultura está hecha, y desde tiempos bien remotos, "desde arriba". Un ejemplo hispánico tan clásico como revelador nos explica bien la cuestión. El marqués de Santillana -siglo XV- en su

6 lbid., 17

7 Carlos Blanco Aguinaga, Julio Rodríguez Puertolas, Iris M. Zavala, Historia social de la literatura española I (Madrid, 1981), 34.

8 En lo que sigue, utilizo, con modificaciones, parte de mi comunicación en el Primer Congreso de Escritores de España, "Por una literatura nacional y popular", 83-84 del volumen de Ponencias y resoluciones (Madrid, 1979).

9 Nils Castro, "Cultura nacional y cultura socialista", Casa de las Américas, XVII.101 (1977), 64. 
famosa Carta prohemio al condestable de Portugal, divide la poesía en tres categorías: sublime (griega y latina), mediocre (la romance), ínfima. $Y$ aquí introduce, en una división que comenzó siendo estética, un evidente concepto de clase, pues los poetas ínfimos son aquellos que "syn ningund orden, regla nin cuento fazen romances e cantares de que las gentes de baxa e servil condición se alegran"10.

Lo que Santillana hace, coincide, más allá del tiempo, con una actitud bien conocida en épocas más recientes; las manifestaciones culturales de las clases dominadas quedan así como subordinadas, dislocadas... son lo que, a los ojos despectivos de la minoría "culta", se llamará manifestaciones de "incultura" o "subculturas"1. Si a esto añadimos todo lo ya dicho acerca del papel de la crítica literaria habitual, en el caso español representada por las tendencias distintas pero complementarias de Menéndez Pelayo y de Menéndez Pidal, y de sus seguidores, tendremos ya una idea bastante aproximada de la identificación entre crítica e historiografía literarias y cultura oficial de la clase dominante.

Quisiera ejemplificar todo lo anterior con algunos casos notorios de la Edad Media castellana. Dejo aparte el ya mencionado asunto del Poema de Mio Cid, elevado por Menéndez Pidal y su escuela a símbolo de la literatura no ya castellana, sino española. Un asunto inicial es el de la lírica tradicional castellana, incorporada a las historias de la literatura española tras unos estudios primeros de Menéndez Pidal en $1919^{12}$. Así disponemos ahora de un corpus de esa lírica, que no es la "oficial", que recoge en forma breve y compendiosa por lo general temas y situaciones propias de la vida popular y de las relaciones de esa vida con la de las clases superiores ${ }^{13}$.

Menéndez Pidal menciona poemas relativos a fiestas públicas y familiares, viajes y romerías, trabajo campesino, amor... ${ }^{14}$ Pero en cuanto a esto último, lo que no dice es que se trata de un amor muy alejado de los alambicados conceptos cortesanos y de su casuística; un amor directo, elemental, tan "popular" como las coplas mismas que lo cantan, claramente sexual los más de los casos, y en el cual aparece también el problema de las relaciones entre las minorías y la casta cristiana dominante, entre villanos y nobles. La temática general, por otro lado, es mucho más amplia de lo que dice Menéndez Pidal. No solamente hay canciones sobre el trabajo o de trabajo, sino también contra ciertos trabajos. La situación de la mujer exige, además, otros temas: la malcasada, la malmonjada, la excesivamente vigilada. Y no falta, sin duda, el anticlericalismo. Se trata de un ejemplo clásico de la otra cultura, la popular, asimilada ya en el teatro de Lope de Vega convenientemente, y en nuestro siglo por los críticos y los historiadores de la literatura, los cuales, sin embargo, suelen rehuir toda referencia a la existencia contrapuesta de las dos culturas y a ciertos aspectos temáticos ya mencionados.

Otro capítulo medieval en buena parte marginado es el referente a la poesía crítica castellana del siglo XV. Se trata, en este caso, de una poesía culta, pero lo suficientemente agresiva y realista como para que se haya conservado con dificultades y haya pasado a las historias literarias como mera curiosidad en el mejor de los casos. Pues ¿qué decir, en

10 Santillana, Poesía completa, II (Madrid, 1980), 214; edición de Manuel Durán.

11 Nils Castro, art. cit., 65.

12 "La primitiva lírica castellana", en España y su historia, I (Madrid, 1957), 753-804.

13 Julio Rodríguez Puértolas, Poesía crítica y satíriça del siglo XV (Madrid, 1981), 338.

14 En lo que sigue, adopto, con modificaciones, lo dicho por mí en la p. 339 del libro citado en la nota anterior. 
efecto, de un poema titulado Libro de miseria de omne, en que la vida de los miserables aparece de este modo tan "naturalista"?

El hombre empobrecido trae capa muy cativa, cuando habe la camisa non puede haber la saya; desfalleçele la calza, trae rota la zapata; por pecados, non ha bragas que pueda cubrir la nalga. La mujer empobrecida trae mezquino tocado, habe rota la camisa e paréçele el costado; muchas son tan malastrugas e de tan mezquino fado, que no tienen con qué cubran el vergonzoso forado.

$¿ \mathrm{O}$ este fragmento del mismo poema, obvio reflejo de la lucha de clases?

Por la culpa del señor el siervo habe laceria; e si el siervo habe culpa, el señor habe la prenda, que quier canten los mayores, los menores han la pena. Onde dize gran verdad el rey sabio Salomón: el siervo con su señor non andan bien a compañón, nin el pobre con el rico non partirán bien quiñón, nin será bien segurada oveja con el león ${ }^{15}$.

Pero es en el siglo XV donde el marginalismo medieval castellano alcanza sus cotas y expresiones más aitas. Así, habría que recordar el caso de los primeros ensayistas, habitualmente judíos conversos, como Alfonso de la Torre con su Visión deleitable de la filosofia (c.1430) y Juan de Lucena con su Vida beata (1463). La obra del primero de los citados es una especie de revisión de los conocimientos medievales, caracterizada de modo muy especial por su racionalismo, inspirado en el filósofo hispano-judío Maimónides. Alfonso de la Torre se burla peligrosamente del concepto cristiano de Providencia, de un Dios que interviene en todo lo que ocurre en este mundo:

Assí el caer de una foja del árbol et matar una araña con el pie et una mosca con la saliva, o pisar un hombre et matar una hormiga, como la destruición de un reino o el quemar una ciudad, o la muerte de una grande multitud de gente ${ }^{16}$.

Un caso especial, y sin duda de los más significativos, es el del aristocrático Enrique de Villena (1383-1434). En las oficialistas Generaciones y semblanzas de Fernán Pérez de Guzmán se dice de Villena, entre otras cosas, que era "ajeno e remoto no solamente a la cavallería, más aún a los negocios del mundo y al regimiento de su casa y hacienda; era tanto inhábile e inepto que era gran maravilla".

Villena mostró un gran interés por las artes mágicas -parte de la realidad vital de su tiempo, no se olvide- y fue criticado por ello, como sigue diciendo Pérez de Guzmán: "non se deteniendo en las sciencias notables e católicas, dexóse correr a algunas viles o raheces, artes de adivinar e interpretar sueños e estornudos e señales"17.

A su muerte, Estado e Iglesia se unieron para llevar a cabo una quema purificadora de parte de la biblioteca de Villena, la compuesta por textos considerados como peligrosos, uno de los ejemplos más tempranos de censura ideológica. Villena no fue considerado como sospechoso exactamente por sus intereses en la "magia", sino por su studia

15 Apud Julio Rodríguez Puértolas, Poesía de protesta en la Edad Medía castellana (Madrid, 1968), 99-100 y 101. 16 Apud Blanco Aguinaga, Rodríguez Puértolas, Zavala, op. cit., I, 193.

17 Ibid., 178. En lo que sigo, adopto, con modificaciones, lo dicho en 178-79. 
humanitatis ${ }^{18}$. Y quizá también por algo más, que podemos ver en su obra fundamental, Los doce trabajos de Hércules (1417). La historia del famoso personaje mitológico aparece tratada en cuatro niveles, siendo el cuarto la aplicación a la realidad social, en extraordinario análisis de la época; así, las doce aventuras de Hércules se aplican a los doce estados que Villena considera. Ha de notarse que su lista incluye a ciudadanos, mercaderes y menestrales, buena prueba de la existencia de una realidad insoslayable para un observador atento y no cegado por su pertenencia a la aristocracia, al contrario de lo que hizo un Juan Manuel, por ejemplo. Humanismo, magia, nueva realidad social: sin duda demasiado para los celosos vigilantes de la ortodoxia religiosa y social de la Castilla de la época.

Pero es en la poesía -el gran género literario del siglo XV castellano- donde lo marginado abunda de manera en verdad sorprendente, y donde la censura de críticos e historiadores se ha ejercitado con fruición mayor. Dejaré aparte, por razones de espacio, poemas satíricos del tipo de Panadera y Mingo Revulgo (por otra parte más conocidos y menos conflictivos); el gran caso es el anónimo Coplas del Provincial, de la época de Enrique IV, poema tan implacable como inútilmente perseguido. Recordaré que esta obra no ha sido publicada completa sino muy ocasionalmente ${ }^{19}$, pues la crítica ha venido siguiendo las puritanas normas de Menéndez Pelayo en su Antología de poetas líricos castellanos, y no sin razón desde su punto de vista, pues como dijera él mismo, en cada estrofa del Provincial

hay, por lo menos, un nombre propio, sobre el cual recae con odiosa monotonía el sambenito de sodomita, cornudo, judío, incestuoso, y, tratándose de mujeres, el de adúltera o el de ramera. Los apellidos más ilustres de Castilla están infamados alli ${ }^{20}$.

Y tras Menéndez Pelayo, la inmensa mayoría de los críticos que mencionan el poema suelen limitarse a denigrar su carácter obsceno y panfletario, sin ocuparse ni poco ni mucho de encuadrar al Provincial en su marco histórico, aquí, acaso más que en otros casos, absolutamente inexcusable.

Es en el enorme caudal poético de los cancioneros castellanos del siglo XV donde se hace preciso detenerse un tanto. Se trata de una poesía que solamente ahora se intenta estudiar de modo científico e histórico, y ello no precisamente por críticos hispánicos, sino por lo general británicos. Como ha dicho Keith Whinnom

Es en verdad increíblemente ciego por parte de los críticos modernos el despreciarla [la poesía cancioneril] como totalmente sin valor para nosotros, por "no realista" y "artificial". (El uso del término artificial es, sin duda y casi siempre, indicación de un fracaso crítico moderno)... Podría verse con facilidad que las escasas piezas que de vez en cuando aparecen en las antologías modernas son justamente las menos típicas del género ${ }^{21}$.

18 Cfr. Nicholas G. Round, "Renaissance Culture and Its Opponents in $15^{\text {th }}$ Century Castille", Modern Languages Review, LVII (1962), 204-15.

19 Cfr. Rodríguez Puértolas, en Poesía de protesta y Poesía crítica, obras ya citadas.

20 Antología de poetas líricos castellanos, II (Santander-Madrid), 289.

21 Op. cit., 15. Cfr. también, del propio Whinnom, "Hacia una interpretación y apreciación de las canciones del Cancionero General de 1511", Filología, XIII (1968-1969), 361-81, y La poesía amatoria cancioneril en la época 
No voy a tratar aquí de esa ceguera de los críticos para la poesía amorosa cancioneril. Me referiré en concreto a tres aspectos claramente marginados dentro de una literatura marginada casi en bloque: los poemas eróticos y "pornográficos"; los poetas conversos; las mujeres poetas. Una línea distinguible en los cancioneros es la poesía habitualmente llamada obscena y pornográfica, la cual, por otro lado, tiene una vieja y noble tradición peninsular, que puede ya encontrarse en abundantes poemas gallegos de Alfonso el Sabio y de otros autores ${ }^{22}$. El tema es tan tabú que un hispanista como Frank Pierce al estudiar lo sexual en Tirant lo Blanc, se ve obligado a declarar lo que sigue:

El asunto general de este artículo es universal, y sin embargo, ha sido más a menudo ignorado por los estudiosos de la literatura que explícitamente tratado, y por razones que, debo decir, tienen la aprobación de quien esto escribe en algunos $\operatorname{casos}^{23}$.

Como dije, más de un crítico no se ha limitado a ignorar este tipo de literatura, sino que se ha permitido censurarla. Así el académico Emilio Cotarelo en su edición del Cancionero de Antón de Montoro (Madrid, 1900), quien, simplemente, sustituye unas palabras del original por puntos suspensivos, o las deja en blanco. Son composiciones, como dice Cotarelo, "que no nos hemos atrevido a suprimir, por más que debieran ser excluidas por su excesiva libertad ${ }^{24}$. En otros casos aún peores, Cotarelo, sin previo aviso, se permite cambiar unas palabras por otras. Por su parte, Samuel Gili Gaya elimina en su edición de Obras de Diego de San Pedro (Madrid, 1950) un poema, "a causa de su carácter obsceno, que nada añadiría a la reputación de su autor"25. Se trata del dirigido a una señora a quien rogó que le besase y ella le respondió que no tenía culo.

Señala el gran erudito Antonio Rodríguez-Moñino que "aunque en toda la literatura española hay una veta alegre y libertina que llega hasta nuestros días, casi siempre (excepto en el siglo pasado) quedaron sus frutos relegados al manuscrito"26. Alude en concreto Rodríguez-Moñino al Cancionero de obras de burlas provocantes a risa (Valencia, 1519), formado con poemas tomados del Cancionero general de 1511, pero con exclusión de algunos textos extraordinarios, como el Aposento en el gordo Jubera. Y mención especial merece la denigrada Carajicomedia, asombrosa parodia obscena del Laberinto de fortuna de Juan de Mena, en que -como antecedente del dieciochesco Arte de las putas de Nicolás Fernández de Moratín- se pasa revista a famosas prostitutas, reales o ficticias, de finales del siglo XV y comienzos del XVI, y a sus habilidades profesionales.

Si bien no todos, ni con mucho, de los conversos que fueron apareciendo en la Península desde 1391 pueden entrar en la categoría de marginados o marginales, lo cierto es que en los cancioneros del siglo XV abundan poetas de tal procedencia, y también directamente judíos, y que no son precisamente ellos los que se mencionan (como no sea de modo anecdótico y, desde luego, discriminatorio) en las historias literarias, sino

de los Reyes Católicos (Durham, 1981).

22 Véanse en Cantigas d'escarnho e de mal dizer (Coimbra-Vigo, 1965), edición de M. Rodrigues Lapa.

23 Pierce, "The Role of Sex in the Tirant lo Blanc", Estudis Románics, X (1962), 291.

24 Edición citada, XXVIII.

25 Edición citada, XXV.

26 Introducción a su edieión del Cancionero general (Madrid, 1958), 23. 
los grandes poetas aristocráticos o conocidos y aceptados por otras razones, culturalistas y oficiales. Así, por ejemplo, nos encontramos con que en el Cancionero de Baena -compilado por un converso en la época de Juan II de Castilla- una parte importante del mismo la forman poetas recién convertidos que se ocupan de puntos difíciles del cristianismo y llegan a polemizar con autores puramente cristianos (Ferrán Manuel de Lando, Fernán Sánchez de Calavera, Garcí Álvarez de Alarcón); digamos también que estos poetas, además, suelen ser autores de violentos poemas de crítica social y política ${ }^{27}$. En el Cancionero general de Hernando del Castillo (Valencia, 1511), que recoge poemas desde la época de Juan de Mena en adelante, la presencia conversa es también notoria, aunque con rasgos muy distintos a los del Cancionero de Baena. En efecto, han pasado y están pasando muchas cosas en Castilla desde los tiempos de Juan II, y ahora en los cancioneros se detecta la ominosa realidad del antisemitismo, en ocasiones virulento. Con todo, los conversos figuran ahí, a veces haciendo ostentación de su condición y diferenciación, polemizando entre ellos o con poetas cristianos viejos. Antón de Montoro es en este sentido un poeta clave, con un especialísimo sentido del humor, como cuando en un poema dedicado a Isabel la Católica, en que pide amainen las persecuciones antisemitas, termina solicitando que, por lo menos, las hogueras inquisitoriales no se enciendan "hasta allá por Navidad, / cuando sabe bien el fuego". En este mismo poema, Montoro declara amargamente su propia situación y la de tantos conversos:

Hice el Credo y adorar,/ ollas de tocino grueso,/ torreznos a medio asar/ oir misas y rezar,/ santiguar y persignar, / y nunca pude matar/ este rastro de confeso, $/[\ldots]$ no pude perder el nombre de viejo puto y judío ${ }^{28}$.

Pero véase al respecto lo que un historiador de la literatura como Ángel Valbuena Prat, en cuyo manual se han formado generaciones de estudiantes españoles, comenta sobre Montoro a propósito de este poema:

Era él un verdadero tipo de judío en lo que se suele entender por el carácter solapado, zalamero y pérfido que en ocasiones suele dar la raza ${ }^{29}$.

Resta por hablar de las escritoras del siglo XV castellano, habitualmente olvidadas. Es la primera cronológicamente Leonor López de Córdoba (1363-1412), autora de unas raras Memorias (c. 1412) en que explica la precaria situación en que quedó su familia -que fue partidaria del rey Pedro I- como consecuencia del entronamiento de los Trastámara:

La nota auténticamente personal, la descripción de un personaje que, aunque estaba bien relacionado, permanecía oscuro sin embargo, y el hecho de que su autora sea una mujer, hacen de esta obra una de las más notables de su tiempo ${ }^{30}$.

$27 \mathrm{Cfr}$. mis dos libros citados en nota 19.

28 Según mi Poesía crítica, 316-17.

29 Valbuena Prat, Historia de la literatura española, I (Barcelona, 1953), 303.

30 Alan D. Deyermond. Historia de la literatura española. I. La Edad Medía (Barcelona. 1973). 275. 
Obra notable, en efecto, pero sólo ocasionalmente mencionada, sin mayores preocupaciones $^{31}$. Algo parecido ocurre con otra prosista del siglo XV, la monja conversa Teresa de Cartagena, autora de algunos tratados religiosos (posteriores a 1450), como Admiraçión de las obras de Dios y arboleda de enfermos. Teresa de Cartagena se vio criticada "como intrusa dentro del mundo masculino de la literatura, y, en la primera muestra conservada de feminismo literario en castellano, defendió el derecho de las mujeres a escribir libros"32. Dice Juan Marichal, prácticamente el único crítico que se ha ocupado con alguna extensión de Teresa de Cartagena, que la monja conversa

declara que la costumbre muestra que los hombres tienen el monopolio de la pluma, pero esto no corresponde a la verdadera naturaleza de la vida humana, y no puede ser un precedente de carácter irrefutable. "No es conveniente ni posible que las mujeres se equiparen en todo a los hombres... pero sí pueden hacerlo en materias literarias" ${ }^{\prime 33}$.

Esta misma idea, pero expresada mucho más libre y abiertamente, aparece en la novela sentimental de Juan de Flores titulada Grisel y Mirabella, donde uno de los protagonistas femeninos dice lo que sigue, desenmascarando el monopolio masculino de lo que hoy llamaríamos "medios de comunicación":

porque en nuestra simplicidad, no ay quien scriue en fauor nuestro, y vosotros, que tenéys la pluma en la mano, pintáys como queréys; por donde no es mengua, sino fuerça, el sofrir a más poder ${ }^{34}$.

Quedan por mencionar las mujeres poetas de los cancioneros del siglo XV. De la única que suele hablarse, y ello mínimamente, es de Florencia Pinar ${ }^{35}$, cuando la realidad es que hay muchas más; un rápido repaso al corpus cancioneril de la época permite observar la presencia de treinta y una mujeres poetas en once cancioneros diferentes. He aquí otro flagrante caso de marginación, agravado ahora por un componente que bien puede denominarse machismo, no lejos del viejo refrán español de la mujer, la pierna quebrada y en casa. Cito una vez más al hispanista Keith Whinnom:

31 Las Memorias de Leonor Lopez de Córdoba fueron publicadas sin excesivo cuidado por Adolfo de Castro en $L a$ España Moderna, 163 y 164 (1902), 12046 y 116-33, respectivamente. Algunos fragmentos aparecieron en la Crestomatía del español medieval de Ramón Menéndez Pidal, II (Madrid, 1966), 522-25. Cfr. más recientemente Reinaldo Ayerbe-Chaux, "Las memorias de doña Leonor López de Córdoba”, Journal of Hispanic Philology, II (1977-1978), 11-33.

32 Deyermond, Edad Media, vol. I de Historia y crítica de la literatura española (Barcelona, 1980; dirigida por Francisco Rico), 393.

33 Marichal, La voluntad de estilo (Madrid, 1971), apud Deyermond/Rico, op. cít., 440-41. Cfr. también del mismo Deyermond, "El convento de dolengias: The Works of Teresa de Cartagena", Journal of Hispanic Philology, I (1976-1977), 19-29.

34 Barbara Matulka, ed., The Novels of Juan de Flores and their European Diffusion (Nueva York, 1931), 350.

35 Sobre Florencia Pinar, cfr. Deyermond, Historia, 358; Edad Media, 303; Traces of the Bestiary in Medieval Spanish Literature (Londres, en prensa). Y Whinnom, art. cit. en nota 21, 367. Por otro lado, Deyermond se ocupa de varias de las mujeres escritoras del siglo XV castellano en "Spain's First Women Writers", que aparecerá próximamente en Images: Women in Hispanic Literature, dirigido por Beth Miller (Universidad de California). 
La distorsión de la historiografía literaria por la apreciación de la literatura y por la terrible actitud victoriana de tanta crítica hispanista, tiene por lo menos dos consecuencias que considero deplorables. Es la primera la tendencia a la adoración de los héroes y a la creación de vacas sagradas. Debemos abandonar la "teoría del héroe"... es algo moralmente insano. Los "grandes" escritores han tenido mucha menos influencia en el curso de la historia literaria de lo que comúnmente se supone; dependen, hasta un grado no bien apreciado, de escritores injustamente marginados... La segunda consecuencia derivada de no mirar con objetividad los hechos de la historia literaria, es ignorar aquello que puede y debe ser una experiencia liberadora... un modo de comunicación que puede sernos de utilidad para percibir nuestras propias limitaciones ${ }^{36}$.

Volvamos, por último, a la cuestión ideológica. El lector y el estudioso de las obras literarias han de atravesar muchas veces un entramado, sutil o grosero, compuesto por las mediaciones impuestas entre el texto y el propio lector por comentaristas, críticos, profesores, páginas culturales de la prensa periódica, propaganda, editoriales, mercado, premios, ferias. Parafraseando a Louis Althusser, todo ello puede dar como resultado que el lector "se representa no el conjunto de las relaciones reales que rigen la existencia de los individuos, sino la relación imaginaria de esos individuos con las relaciones reales en las que viven"37.

Cómo se logra teóricamente tal efecto ya ha sido, en parte, visto al comienzo de este trabajo. Hemos visto también ejemplos concretos. Añadiré ahora alguna ilustración de cómo cierta crítica funciona, limitando mis comentarios personales al mínimo, pues creo que los casos que voy a citar hablan por sí solos. Cuando Marcelino Menéndez Pelayo en sus Orígenes de la novela estudia al infante Juan Manuel y su Conde Lucanor y lo compara con Boccaccio, llega a defender la superioridad del castellano sobre el italiano debido a la falta de "lubricidad" del primero" ${ }^{38}$. Cuando Ramón Menéndez Pidal traza el fascinante panorama de lo que él considera "caracteres primordiales de la literatura española", dedica una sección completa a la "austeridad moral" de esa literatura, y escribe:

y bien puede decirse que tal austeridad moral en la literatura [española] es rasgo fisonómico de los más persistentes a través de todos los tiempos, el más claramente delineado ${ }^{39}$.

Y Menéndez Pidal desarrolla lo dicho por Menéndez Pelayo. Frente a las pecaminosas canciones francesas del siglo XIII, de amor adúltero, nosotros podemos oponer, dice, "la poesía del amor virginal, efusiones de la doncellita conversadas con su madre"; frente a la obscenidad de -otra vez-Boccaccio, la austeridad de -otra vez- Juan Manuel; frente a las eróticas aventuras de Tristan y de Lanzarote, el puritanismo ibérico del Amadís. Llega Menéndez Pidal a afirmar que cuando el impúdico vaudeville francés es adaptado al sur de los Pirineos, "no puede presentarse ante el público español sino bajo muchos velos" 40 . Discutir aquí quién pone o quita esos velos nos llevaría demasiado lejos.

36 Whinnom, Spanish Literary Historiography, 23-24.

37 Althusser, Escritos, 1968-1970 (Barcelona, 1975), 149.

38 Orígenes de la novela, I (Madrid, 1962), 143-45.

39 Menéndez Pidal, en España y su historia, II, 633.

40 Menéndez Pidal, ibid., 640; las referencias anteriores, en 638-39. 
Cierto que este tipo de puritanismo no ha sido ni es exclusivo del hispanismo; recordemos dos casos bien espectaculares de nuestro avanzado siglo XX: el Ulysses de James Joyce y Lady Chatterley's Lover, de D.H. Lawrence, prohibidos durante largos años en Inglaterra, Estados Unidos y otros países. Pero en nuestro caso, en el caso español, tales actitudes son bien castizas y tradicionales, y no sólo por lo que a cuestiones sexuales se refiere. La persecución religiosa, política y moral de la ciencia y de la cultura durante el llamado Siglo de Oro es cosa tan conocida como reveladora ${ }^{41}$. En el ámbito artístico, recuérdese lo ocurrido con el que seguramente es el único desnudo femenino de la pintura clásica española, La Venus del espejo, de Velázquez: realizada clandestinamente, se conserva, claro está, no en el Prado, sino en un museo de Londres. Regresando a lo literario, voy a limitarme a citar, todavía en ese mismo Siglo de Oro, lo dicho por fray Luis de Alarcón en una obra titulada, apropiadamente, Camino del cielo, de 1550:

Se siguen graves daños de leer libros mundanos... ¿Qué otra cosa son los libros mundanales sino tizones infernales? Del número de estos libros son el latino Ovidio y Terencio en algunas obras y otros tales; en romance un Amadís o Celestina, y otros semejantes ${ }^{42}$.

No puede sorprender que un hispanista norteamericano como Otis H. Green haya publicado cuatro volúmenes titulados Spain and the Western Tradition ${ }^{43}$, en la habitual línea que identifica lo español con lo castellano, lo occidental, lo católico y lo puritano, ignorando a musulmanes, judíos, conversos y heterodoxos. Como ha dicho Francisco Márquez Villanueva, "la neta resultante es una historia sin Inquisición, sin conversos, sin limpieza de sangre"

Vengamos, en fin, a tiempos más recientes. Es bien sabido que en la textura de los regímenes dictatoriales figura de manera predilecta el ejercicio de la censura. Así ocurrió, y de qué modo, bajo el franquismo. Mencionaré solamente algunos ejemplos pertenecientes al mundo intelectual y literario y también al educativo. Así, ¿quiénes eran los defensores de la República? De este modo los definía en diciembre de 1936 José María Pemán -director entonces de la Comisión Depuradora de Cultura y Enseñanza-, al tiempo que anunciaba drásticas medidas contra "los envenenadores del alma popular":

Los individuos que integran esas hordas revolucionarias cuyos desmanes tanto espanto causan, son, sencillamente, los hijos espirituales de catedráticos y profesores que a través de instituciones como la llamada "Libre de Enseñanza" forjaron generaciones incrédulas y anárquicas ${ }^{45}$.

El propio general Franco explicaba así las tareas intelectuales de su régimen en 1943, durante las ceremonias de inauguración de la nueva Ciudad Universitaria de Madrid:

41 Cfr., por ejemplo, tres estudios relativamente recientes: Antonio Márquez, Literatura e inquisición en España, 1478-1834 (Madrid, 1980); Henry Méchoulan, El honor de Dios (Barcelona, 1981); Luis Gil Fernández, Panorama social del humanismo español, 1500-1800 (Madrid, 1981).

42 Apud Américo Castro, De la edad conflictiva (Madrid, 1963), 167-68.

43 Madison, 1963-1966. Hay, claro está, edición española.

44 Márquez Villanueva, Relecciones de literatura medieval (Sevilla, 1977), 143.

45 Apud Blanco Aguinaga, Rodríguez Puértolas, Zavala, op. cit., III $\left(2^{\mathrm{a}}\right), 81$. 
Contra los protagonistas pseudo científicos de la heterodoxia hispana, máximos responsables de la catástrofe ideológica y moral de que hubo que redimir con las armas a nuestro pueblo, España reafirmó su fe en el preștigio histórico de su tradición científica, incontaminada de europeísmo de importación ${ }^{45}$.

La censura se ejercitó incluso en autores tan respetados como Pérez Galdós. Maximiliano García Venero se preguntaba, y se respondía a sí mismo, lo que sigue: "¿Qué debe hacer nuestra generación, que si no es católica no será nada ni servira al destino de la Patria, ante la diversidad galdosiana? Lo prudente parece separar lo útil y beneficioso de lo vitando" ${ }^{\text {47 }}$.

¿Y Cervantes? Véase lo que un profesor de literatura, Manuel de Montoliu, escribió recién terminada la guerra civil:

El Quijote no es el libro de la actualidad española... Su protagonista no nos ofrece la ejemplaridad oportuna en estos momentos trascendentales de la historia de España. El Caballero de la Triste Figura, encarnación suprema de la filosofía del desengaño, es el heraldo de la inminente debilitación de la unidad espiritual del Imperio ${ }^{48}$.

Imposible dejar de citar algo muy conocido: en un manual de literatura española utilizado en los colegios de jesuitas durante muchos años, el estudio de Pío Baroja comenzaba sencillamente así: "Pío Baroja: impío". Difícilmente la imposición ideológica y la manipulación cultural y educativa fueron alguna vez tan brutales y groseras en España como durante la dictadura franquista. El pedagogo oficial del Régimen en la época heroica, Adolfo Maillo, explicaba así el propósito de su libro fundamental, titulado Educación y revolución:

Las páginas siguientes han nacido con el designio de combatir las ideas de emancipación del hombre... Se utilizará como procedimiento educativo fundamental la "ascesis", es decir, el ejercicio de todas las posibilidades psicofísicas del escolar con carácter represivo y sublimador de las tendencias espontáneas y naturales... Elevamos el principio de la disciplina, el espíritu de servicio y la represión ascética de los impulsos naturales... Se impone, como una necesidad urgentísima, un tipo de educación inspirado en principios netamente medievales ${ }^{49}$.

Si esto es así, obviamente que Ernesto Giménez Caballero, teórico número uno del fascismo español, tenía toda la razón y la lógica consigo al dirigirse apocalípticamente a los niños de 1943:

... ¡Escuchad bien esto y para siempre, niños españoles!: ¡el que de vosotros olvide su lengua española o la cambie por otra, dejará de ser español y cristiano! ¡Por traición

46 Apud Juan de Dios García, El Régimen del I8 de julio, modelo ideológico (Madrid, 1977), 42.

47 Introducción a su Antología nacional de Galdós, I (Madrid, 1943), 5.

48 "En busca del poeta nacional de España", La Nación (Buenos Aires, 23-X-1939).

49 Apud García, op. cit., 31-32 
contra España y pecado contra Dios! ¡Y tendrá que escapar de España! Y cuando muera, su alma traidora ¡irá al infierno $!^{50}$

Como diría don Américo Castro, los ángeles de la Contrarreforma no han dejado nunca de proyectar su sombra protectora sobre la sociedad y la cultura españolas. Unos ángeles que acaso no tienen sexo, pero sí tienen ideología. Y también el poder.

Naturalmente, mucho de lo hasta aquí citado son ejemplos extremos de imposición ideológica desnuda y brutal. Hoy, en la mayor parte del ámbito socio-cultural en que nos movemos las cosas suelen ser mucho más inteligentes, refinadas y sutiles, mas no por ello menos desprovistas de intencionalidad y carga ideológica. Pues lo que ocurre, como dice Juan Villegas, es que el discurso crítico habitual abstrae el discurso literario de su

contextualidad y pretende asignarle un valor universal de modo que "interpreta" el texto por representar la universalidad fundada en lo particular, única justificación dentro de nuestro contexto crítico para describir o comentar... Creo que la tarea... debe ser precisamente lo contrario: la historización y la ideologización de los textos, revelar lo ideológico de las críticas que se dicen científicas, objetivas y sustentadas en valores absolutos ${ }^{51}$.

\section{O como lo ha escrito Hernán Vidal:}

El crítico literario queda confinado a los departamentos de idiomas, donde normalmente se validan aproximaciones teóricas y metodológicas esencialistas, aplicadas dentro de los marcos de las literaturas nacionales... Ello resulta en la colección de varios especímenes de investigadores, elegidos de acuerdo con las tendencias críticas reconocibles en el mercado del momento... En última instancia se produce la mayor distorsión posible: las literaturas nacionales dejan de ser objeto de estudio en sí para convertirse en materia prima para la demostración del último artefacto teórico..., desarrollar una noción de lectura individuaiisk $k^{32}$.

Frente a todo ello, en efecto, se alzan todavía las válidas palabras de León Trotsky, para quien la verdadera investigación literaria

No "recrimina" en absoluto a un poeta por los pensamientos y sentimientos que expresa, sino que plantea cuestiones de un significado más profundo, por ejemplo: ¿a qué tipo de sentimientos corresponde una determinada obra de arte con todas sus peculiaridades, cuál es el condicionamiento social de estos pensamientos y sentimientos, qué lugar ocupan en el desarrollo histórico de una sociedad y de una clase? ?3 $^{53}$

50 España nuestra. El libro de las juventudes de España (Madrid, 1943); apud García, op. cit., 30.

51 Villegas, "El discurso dramático-teatral latinoamericano y el discurso crítico: algunas reflexiones estratégicas", Latin American Theatre Review (otoño 1984), 10-11.

52 Vidal, Sentido y práctica de la crítica literaria socio-histórica: panfleto para la proposición de una arqueología acotada (Minneapolis, 1984), 4-5.

53 Trotsky, Sobre arte y cultura (Madrid, 1973), 88. Recientemente han aparecido, en el mundo del hispanismo, estudios pertinentes a las tesis aquí mantenidas. Por ejemplo, y además de lo citado: número especial de Ideologies and Literature, IV. 16 (1983), Problemas para la crítica socio-histórica de la literatura: un estado de las artes; 
incluye veintinueve trabajos, algunos de ellos de extraordinario interés, como los de John Beverly, Juan Ignacio Ferreras, Constance A. Sullivan, Jean Franco, Hernán Vidal o Tom Lewis. Cfr., en otro orden, Julio Rodríguez Puértolas, "La crítica literaria marxista", en Introducción a la crítica literaria actual, dirigido por Pedro Aullón de Haro (Madrid, 1984), 209-50. 